\title{
The Relationship between Videogame Use, Deviant Behavior, and Academic Achievement among a Nationally Representative Sample of High School Seniors in the United States
}

\author{
Luis Concepcion $^{1, *}$, Marilyn Nales-Torres ${ }^{2}$, Ana Rodriguez-Zubiaurre ${ }^{3}$ \\ ${ }^{1}$ Human Services, Liberty University, Lynchburg, VA, United States \\ ${ }^{2}$ Nova Southwestern University, Fort Lauderdale, FL, United States \\ ${ }^{3}$ Management (Economy and Tourism), Universidad de las Palmas de Gran Canaria, Spain \\ *Corresponding author: Irconcepcion@liberty.edu
}

\begin{abstract}
This study examined the relationship between video games and academic performance. Previous research has been mixed with some studies indicating a negative relationship, while others have indicated a positive association. The influence of a moderating variable, deviant behavior, was investigated, as it is hypothesized that students who frequently use videogames and participate in deviant behavior will experience low academic achievement, whereas videogame use will not affect the achievement of students who do not participate in deviant behavior. Using correlation and hierarchical regression analysis of a national sample (the 2013 "Monitoring the Future” (MTF) survey [1]), no statistically significant moderating effect for deviance was discerned. Without a moderating effect, students engaging in a greater number of video games had higher academic achievement, as measured in GPA.
\end{abstract}

Keywords: videogames, academic achievement, deviant behavior, adolescents

Cite This Article: Luis Concepcion, Marilyn Nales-Torres, and Ana Rodriguez-Zubiaurre, "The Relationship between Videogame Use, Deviant Behavior, and Academic Achievement among a Nationally Representative Sample of High School Seniors in the United States.” American Journal of Educational Research, vol. 4, no. 16 (2016): 1157-1163. doi: 10.12691/education-4-16-6.

\section{Introduction}

Academic achievement (achievement) is a key measure to understand the success, or lack thereof, of educational activities that a particular student is subjected to over a period of time [77]. This construct is generally measured through tests or evaluations, although there is not broad agreement across the field of education on how to measure it, nor is there broad agreement on which areas are most important in assessments, such as practical skills or knowledge of facts or memorization. Hence, many achievement studies focus on test scores or student grades, grade point average (GPA) being the most commonly used way to measure academic achievement $[2,5,55]$

Academic achievement is important because high school students who struggle with school grades are more likely to have individual, institutional, and population level problems [25]. At the individual level, low achievement causes short-term problem behavior and school dropout, and can also disrupt educational and professional paths into adulthood [26,27,28]. At the institutional level, students with achievement issues can create chaos and destabilize the overall organizational goals [29]. At the population level, widespread achievement failure has long been known to cause drastic changes in a given population's rates of fertility, mortality, marriage, as well as unemployment through the correlation between achievement and the development of human capital [30,31,32]. High school students with low achievement are less likely to graduate high school [33]; to have good college outcomes [34]; and have job and earnings success [35].

A number of variables have been found to predict academic achievement, including socioeconomic status $[36,37,38,39]$, general and emotional intelligence $[56,57,58,59,60]$, and social support [61,62,63,64]. Recently, researches have focused their investigations on the rising use of technology among high school students, specifically videogames [3]; although, research has produced conflicting results in this regard with some studies finding a negative effect for videogame use on achievement $[8,10,13,14,40,41]$, and other studies finding a positive one $[11,12,17]$. In the present study, whether high school students' deviant behavior may explain this disparity in the literature is investigated.

\section{Literature Review}

\subsection{Videogames and GPA}

Technology use has been rapidly increasing among high school students, with adolescents spending more time 
with mobile devices. In addition to online entertainment and social media, many adolescents also spend considerable amounts of time playing videogames. According to the Pew Research Center, 97\% of adolescents age 12-17 play videogames in various media [3].

\subsubsection{Negative Effects of Videogame Use on Academic Achievement}

Although several studies have linked videogame use to social outcomes, such as increased aggressive behavior in teenagers $[4,9]$, recent research has sought to determine the relationship between videogame use and academic achievement. Anand [13] studied the relationship between video game use and grade point average (GPA) and observed an inverse relationship between GPA and daily use of video games. Weaver, Kim, Metzer, and Szendrey [10], found in 2013 that students that reported high use of video games also reported lower grade point averages (GPA) which, according to the Weaver et al, is conssitent with the findings of previous research by Anand [13], Harris and Williams [40], and Stinebrickner and Stinebrickner [41]. Arnand [13] in 2007 found that as video game use increases, GPA and SAT scores decrease.

Anand [13] found that, increased use of video games decreased the GPA of college students in the United States. A study by Burgess et al [14] suggests that videogames may be associated with lower GPA because gamers report playing video games to avoid homework. Similarly, Boo found [15] a negative correlation between gaming and motivation, suggesting that students who spend more time playing videogames are less motivated to complete homework and other class assignments, thus explaining their lower GPAs.

\subsubsection{Positive and Neutral Effects of Videogame Use on Academic Achievement}

Not all studies have found a negative correlation between videogame use and GPA.

Many other studies have found neutral or even positive associations between videogame use and achievement. A 1986 study by McCutcheon and Campbell [17] conducted with college psychology students found no significant difference between frequent and infrequent players in respect to their GPAs. Moreover, it was found that infrequent players had significantly higher scores on psychology exams. Hamlen [11] found in 2013 that video game strategies were highly related to GPA, and could be a successful predictor of good school grades. In another 2014 study, Ku, Kwak, Yurov, and Yurova [12] found among other things that playing videogames on personal computer make statistically significant contributions to GPA on IT college students.

\subsubsection{A Theoretical Background for the Effect of Videogames on Achievement}

As of yet, it is unclear why some studies have found a negative effect for videogames on GPA, while others have found a neutral or positive effect. Burgess, Stermer, and Burgess in 2012 found [14] that video gamers had lower GPA, but this finding varied by gender. In this study [14], the moderating effect of gender was observed because males were shown to spend more hours per week on gaming than did females. Burgess et al. conducted separate regression analyses for males and females and found that gaming negatively correlated with achievement among males but not females.

Cranton [16] stated that it may not be the medium (i.e., the videogame) itself but perhaps the information that is transmitted through the videogame that affects student achievement. Videogames that transmit positive content such as "Mario," may be associated with higher achievement [67] because they could improve a person's sense of well-being $[65,66]$, which has been shown to increase achievement [75]. Seligman [66] believes that gaming can promote people's emotions and quality of relationships in a positive direction. On the other hand, videogames that transmit negative content, such as, "God of War," "Hitman," and "Gears of War" series, may be associated with lower achievement since the violence in these games are shown [68] to increase aggressive thoughts, feelings, and behaviors, and decreased prosocial helping, and could [69] become immune to violence and, prone to violent acts themselves, and could lose empathy. Losing empathy, in turn, could cause high school students to earn a lower GPA [78].

Differences in the sampling methods of individual studies may also help explain the disparity in the results. For example, a strong negative effect was found by Burgess et al [14] who sampled 671 college students, a group who is more vulnerable to the impact of videogame use because of susceptibility to violent behavior. In contrast, Hamlen [11] found no effect for videogame use in a sample of 113 children and adults that completed an online survey. This disparity makes sense because, if the effects are only found among specific types of students, we would expect to find no effect of videogame use on academic achievement in a large, broad international sample. This is exactly what Drummond and Sauer [18] found in a broad sample of 192,000 students across 22 countries, suggesting that more work needs to be done to identify the critical moderating variables in this relationship.

\subsection{Moderating the Effect of Videogames and Achievement: Why is Deviance Important?}

In order to understand the effects of gaming on achievement, it is important to understand the moderating effect that deviance may have on this relationship. Although not previously explored in the literature, individual differences deviant behavior (i.e., behavior that differs from average experience [6], such as criminal behavior) may help explain why videogame use is harmful to the achievement of some students but not others. Deviance may moderate the relationship between videogame use and achievement. That is, students who frequently use videogames and participate in deviant behavior may experience low GPA, whereas videogame use will not affect the GPAs of students who do not participate in deviant behavior. This potential moderating effect could be explained by the theory of flow [45first defined as a holistic sensation that people have when they act with total involvement by Csikszentmihalyi in 1975 [45]. Murphy stated [46] that flow, the positive psychological state that occurs when a person perceives a balance between challenges and ability, is one of the main reasons why individuals become immersed in videogames. 
The time spent playing videogames takes significant time away from school duties. When this is combined with the time spent participating in deviant behavior, students may not have enough time left over to take care of their academic responsibilities. As of yet, this relationship has not been explored in the literature.

The present study extends the literature by (1) investigating the relationship between videogame use and academic achievement in a nationally representative sample of U.S. high school seniors and (2) exploring the possible moderating effect of deviant behavior.

\section{Method}

\subsection{Participants}

All the data were analyzed from a nationally representative sample of US high school seniors as surveyed by the "Monitoring the Future "MTF: [1] study (2009-2013, Weighted $N=67,822$ [1]. MTF is a nationally representative cross-sectional study of US high school students. Approximately 15,000 high school seniors (12th graders) are surveyed every year from approximately 130 public and private schools throughout 48 states. MTF uses a multi-stage random sampling procedure: geographic areas are selected, then schools within areas are selected, and then classes within schools are selected. Since the main outcome (heroin use) is rare, in order to have adequate power, this analysis focused on aggregated data collected from the five most recent cohorts with available data (2009-2013). MTF protocols were approved by the University of Michigan Institutional Review Board (IRB) and the authors' IRB deemed this secondary data analysis exempt from review. MTF main data collection involves a series of large, annual surveys of nationally representative samples of public and private high school students throughout the US. The 2013 sample sizes were about 15,200, 13,300, and 13,200 in 8th, 10th, and 12 th grades, respectively. In all, about 41,700 students in 389 secondary schools participated.

\section{Measures}

\subsection{Academic Achievement}

Academic achievement was measured with: "Which of the following best describes your average grade so far in high school?” The possible answers were: $9=" \mathrm{~A}(93-100) "$ 8="А- (90-92)" 7="B+ (87-89)" 6="B (83-86)" 5="B- (8082)" 4="C+ (77-79)" 3="C (73-76)" 2="C- (70-72)" 1="D (69 or below)." Central tendencies measure of the variable aligned with national high school student 2009 GPA data obtained from the National Center for Education Statistics [21]. The average grade in the sample was 6.54 (SD = 1.91), which was equivalent to a $B$ average. The variable was approximately normally distributed, with skewness of -.61 (SE = .02) and kurtosis of -.25 (SE = .04).

\subsection{Videogame Use}

Gaming was measured with: "About how many hours a week do you spend playing electronic games on a computer, TV, phone, or other device?" The possible answers were: $1=$ "None" $2=$ "Less than 1 hour" $3=$ "1-2 hours" $4=$ "3-5 hours" $5=$ "6-9 hours" $6=$ "10-19 hours" $7=$ "20-29 hours" $8=$ "30 or More" $9=" 40$ or More." The average amount of videogame use in the sample was 4.23 $(\mathrm{SD}=2.37$ ), corresponding to three to five hours per day. Self-reported videogame use was approximately normally distributed, with skewness of .48 $(\mathrm{SE}=.06)$ and kurtosis of $-.65(\mathrm{SE}=.11)$.

\subsection{Deviant Behavior}

I selected the following variables: (1) Frequently stealing less than \$50; (2) Frequently stealing over \$50; (3) Frequently stealing vehicle parts; (4) Frequent trespassing of buildings; (5) Damaging other's property on purpose; (6) Being under the influence of marihuana; and (7) Being arrested by police. Deviant variables were selected by matching frequent deviant traits by youth taken from FBI crime reports for 2013 and 2014 and the information and description contained in the MTF data set in order to provide for a proper technique that could be replicated, and one that relates to the population the survey belongs to [24]. A principal components analysis (PCA) was conducted using SPSS to examine the dimensionality of the items. Although two components had eigenvalues greater than one, the second eigenvalues was very close to one, and a visual examination of a scree plot suggested a one-factor solution. Because all of the items had loadings of at least .40 on the first factor, a single composite score was created for each participant using the PCA regression weights from the first factor. The resulting composite variable was severely positively skewed, with a skewness of 5.40 (SE = .06) and kurtosis of 39.19 ( $\mathrm{SE}=.11)$. The majority (97 percent) of the participants reported zero deviant behavior. The new scale obtained had a Cronbach's Alpha reliability of 0.73 , which is adequate for psychometric purposes.

\section{Analytic Approach}

After examining the correlations between key study variables and testing the assumptions of the analysis, I tested my hypotheses using a three-step hierarchical linear regression [75]. In the first step, I tested to see whether videogame use predicted academic achievement. In the second step, deviant behavior was added to the model to see if it predicted academic achievement controlling for videogame use. Finally, I added the cross-product term representing the interaction between videogame use and deviant behavior. The equation for the final model was:

$$
\widehat{Y}=\mathrm{b} 1 \mathrm{X}+\mathrm{b} 2 \mathrm{Z}+\mathrm{b} 3 \mathrm{XZ}+\mathrm{b} 0 \text {, }
$$

where $\hat{Y}$ is the expected level of academic achievement, $\mathrm{X}$ is videogame use, $\mathrm{Z}$ is deviant behavior, and $\mathrm{XZ}$ is the cross-product term representing the interaction between videogame use and deviant behavior.

\section{Results}

\subsection{Correlation Analysis}

Correlations between key study variables are reported in Table 1. Surprisingly, those who reported the highest 
levels of videogame use earned above-average grades. There was a small positive significant correlation between videogame use and grades, $r(1725)=.05, p<.05$. There was no significant correlation between deviant behavior and grades or between deviant behavior and videogame use.

Table 1. Correlations Among Key Study Variables $(\mathrm{N}=\mathbf{1 2}, 383)$

\begin{tabular}{lll}
\hline & Deviant Behavior & Academic Achievement \\
\hline Videogame Use & .04 & .05 \\
Deviant Behavior & & -.00 \\
\hline$* p<05$ &
\end{tabular}

$* p<.05$.

\subsection{Assumptions}

Before interpreting the results of the regression analysis, I tested to ensure that the assumptions of the analysis had been met. Descriptive statistics and a visual examination of a histogram confirmed that error terms were approximately normally distributed, with a skewness of $.67(S E=.06)$ and kurtosis of -.18 $(S E=.12)$. Furthermore, a visual inspection of a scatterplot revealed that the error terms were approximately normally distributed along all predicted values of the dependent variable with no conspicuous fanning. Thus, the assumptions of normally distributed residuals and homoscedasticity were supported.

\subsection{Hierarchical Regression Analysis}

Results are reported in Table 2. In Step 1 of the hierarchical linear regression analysis, videogame use was a significant predictor of academic achievement $(B=.05$, $p<.05$ ), but it explained only a very small amount of the variation in achievement $(R 2=.003)$. Contrary to expectations, adolescents who reported spending more time playing videogames actually reported slightly higher grades than those who spent less time playing videogames. In Step 2, deviant behavior was not a significant predictor of academic achievement $(B=-.02, p=.53)$, and it did not significantly predict any additional variation in achievement $(\triangle R 2=.000)$. That is, adolescents who reported engaging in a lot of deviant behavior earned the same grades as those who participated in little or no deviant behavior. Finally, in Step 3, the interaction between videogame use and deviant behavior was also found to be non-significant $(B=-.08, \mathrm{p}=.15)$, and it did not explain any additional variation in academic achievement $(\Delta R 2=.001)$. This meant that, contrary to expectations, the effect of videogame use on academic achievement was not moderated by deviant behavior.

Table 2. Results of Hierarchical Regression Analysis

\begin{tabular}{llll}
\hline & Step 1 & Step 2 & Step 3 \\
\hline Videogame Use & $.05^{*}$ & .05 & .05 \\
Deviant Behavior & -.02 & .05 & \\
Videogame Use x Deviant Behavior & & & -.08 \\
R2 & $.003^{*}$ & .003 & .004 \\
$\Delta \mathrm{R} 2$ & $.003^{*}$ & .000 & .001 \\
\hline
\end{tabular}

Notes. Dependent variable is academic achievement. Standardized coefficients are shown.

${ }^{*} p<.05$.

\section{Discussion}

A number of variables have been found to predict academic achievement among high school students, including deviance and videogame use. Given the discrepancies in the literature regarding the relationship between videogame use and achievement, it is important to study these relationships among a large nationally representative sample and to explore the conditions under which videogames may be harmful to students' achievement. The present study also examined the hypothesis that videogame use has a negative effect on students' achievement when these students also participate in higher levels of deviant behavior.

There was a small positive correlation between videogame use and grades. Those who spent more time playing videogames were slightly more likely to earn higher grades. Deviant behavior was unrelated to grades. There was no interaction between videogame use and deviant behavior; that is, the relationship between videogame use and academic achievement did not depend on deviant behavior.

The results of this investigation are consistent with prior literature and, in some cases, disagree with prior studies. Results were consistent with McCutcheon and Campbell [17] and Hamlen [11] who found no relationship between videogame use and academic achievement. However, results were inconsistent with Anand [13] and Weaver, Kim, Metzer, and Szendrey [10], as well as Anand [13], Harris and Williams [40], and Stinebrickner and Stinebrickner [41] who found a negative correlation between deviant behavior and achievement. Thus, although the theory of flow may explain some adolescents' immersed involvement in the videogame experience, there is no evidence that this negatively affects their academic performance, even when combined with other time-consuming tendencies, such as participation in deviant behavior.

For parents, teenagers, and educators, the results of this study suggest that videogames may not negatively influence a student's GPA, so parents could change any negative preconceptions of their children's videogame use, and its possible influence on GPA. Students could engage in constructive conversations with their parents regarding their use of videogames, and the possible positive influence of this use on their grades. Educators finally could better advice parents and students alike on the possible positive effects of gaming, and start seeing videogame use as another tool for possibly increasing student's GPA. For parents, teenagers, and educators, is also good to know that, even though deviant behavior does affect grades, this construct is not shown to moderate the relationship between videogame use and GPA as well.

\subsection{Limitations and Need for Further Study}

The dataset used from the MTF survey was valuable to the present study because of the sampling methods utilized and because it included measures of achievement and videogame use typically unavailable in a dataset of this size. The main limitation in using the achievement and gaming variables were that they are self-reported, and there is the possibility that teenagers will lie about or inadvertently misreport their grades, videogame use, or criminal activity, especially teenagers engaged in deviant behavior. However, since grade distribution data paralleled national norms [79], there is no evidence that achievement data were misreported. There is also the 
possibility that GPA, even when accurately reported, may not be a valid measure of academic achievement because tracking policies have been found to lead to grade inflation [80]. Videogame use and deviant behavior may be contributing to poor achievement, but this diminished achievement may not be reflected on the students' report cards. Future studies should include standardized measures of achievement and continue to focus on understanding what moderates the relationship between gaming and achievement. In example, a future moderating study could try to understand if video games ratings, violent or not, moderates this relationship, and the time each is engaged in. Also, it is imperative to measure violent vs. nonviolent video games influence on GPA.

\section{Acknowledgement}

The corresponding author wishes to acknowledge God, Creator of heaven and earth, for the opportunity to live, to study, and to further my education while humbly contributing a small brick to the "Big Wall" of the research field.

\section{References}

[1] Johnston, L. D., Bachman, J.G., O'Malley, P.M., \& Schulenberg, J.E. (2013). Monitoring the Future: A Continuing Study of American Youth (12th-Grade Survey). ICPSR35218-v2. Ann Arbor, MI: Inter-university Consortium for Political and Social Research [distributor], 2015-03-26.

[2] Ward, A., Stoker, H. W., \& Murray-Ward, M. (1996). Achievement and ability tests-Definition of the domain. Educational Measurement, 2, 2-5.

[3] Lenhart, A., Kahne, J., Middaugh, E., Macgill, A. R., Evans, C., \& Vitak, J. (2008). Teens, video games, and civics: teens' gaming experiences are diverse and include significant social interaction and civic engagement. Pew internet \& American life project. Retrieved online from:

http://www.pewinternet.org/2008/09/16/teens-video-games-andcivics/.

[4] Ainin, S. A., Naqshbandi, M. M., Moghavvemi, S., \& Jaafar, N. I. (2015). Video Games Do Affect Social Outcomes: A MetaAnalytic Review of the Effects of Violent and Prosocial Video Game Play. Personality \& Social Psychology Bulletin, 40(5), 578-589.

[5] York, T. T., Gibson, C., \& Rankin, S. (2015). Defining and measuring academic success. Practical Assessment, Research \& Evaluation, 20(5), 2.

[6] Clinard, M., \& Meier, R. (2015). Sociology of deviant behavior. New York, NY: Nelson Education.

[7] Wood, E., Zivcakova, L., Gentile, P., Archer, K., De Pasquale, D., \& Nosko, A. (2016). Examining the impact of off-task multitasking with technology on real-time classroom learning. Computers \& Education, 58(1), 364-374.

[8] Anderson, C. A., \& Dill, K. E. (2000). Video games and aggressive thoughts, feelings, and behavior in the laboratory and in life. Journal of personality and social psychology, 78(4), 772.

[9] Ferguson, C. J. (2011). Video games and youth violence: A prospective analysis in adolescents. Journal of youth and adolescence, 40(4), 377-391.

[10] Weaver, J., Kim, P., Metzer, R. L., \& Szendrey, J. M. (2013). The impact of video games on student GPA, study habits, and time management skills: What's the big deal? Issues in Information Systems, 14(1), 122-128.

[11] Hamlen, K. (2013). Video game strategies: Better predictors of GPA than homework strategies?. In R. McBride \& M. Searson (Eds.), Proceedings of Society for Information Technology \& Teacher Education International Conference 2013 (pp. 21152117). Chesapeake, VA: Association for the Advancement of Computing in Education (AACE). Retrieved online from https://www.learntechlib.org/p/48415.
[12] Ku, C. H., Kwak, M., Yurov, K., \& Yurova, Y. (2014). A Study of the Influence of Gaming Behavior on Academic Performance of IT College Students. Paper presented at Twentieth Americas Conference on Information Systems, Savannah, GA (pp. 1-11).

[13] Anand, V. (2007). A study of time management: The correlation between video game usage and academic performance markers. CyberPsychology \& Behavior, 10(4), 552-559.

[14] Burgess, S. R., Stermer, S. P., \& Burgess, M. C. (2012). Video game playing and academic performance in college students. College Student Journal, 46(2), 376.

[15] Böö, R. (2014). Video game playing, academic performance, educational activity, and motivation among secondary school students. Retrieved online from http://www.divaportal.org/smash/get/diva2:729260/FULLTEXT01.pdf.

[16] Craton, J. (2011). The Effect of Videogames on Student Achievement. Retrieved online from http://www.acsd.org/article/the-effect-of-videogames-on-studentachievement/.

[17] McCutcheon, L. E., \& Campbell, J. D. (1986). The impact of video game playing on academic performance at a community college. Community/Junior College Quarterly, 10(1), 59-63.

[18] Drummond, A., \& Sauer, J. D. (2014). Video-games do not negatively impact adolescent academic performance in science, mathematics or reading. PloS one, 9(4), e87943.

[19] Hayes, A. F. (2012). PROCESS: A versatile computational tool for observed variable mediation, moderation, and conditional process modeling. Retrieved online from http://is.muni.cz/el/1423/podzim2014/PSY704/50497615/hayes_2 012_navod_process.pdf.

[20] California State University. (2016). IBM SPSS Statistics 22. Retrieved online from:

https://www.calstatela.edu/sites/default/files/groups/Information\% 20Technology\%20Services/training/pdf/spss22p3.pdf.

[21] Nord, C., Roey, S., Perkins, S., Lyons, M., Lemanski, N., Schuknecht, J., \& Brown, J. (2011). National Center for Education Statistics, Institute of Education Sciences, America's High School Graduates: Results of the 2009 NAEP High School Transcript Study. Retrieved online from http://nces.ed.gov/pubsearch/pubsinfo.asp?pubid=2011462.

[22] Yonezawa, S. (2000). Unpacking the black box of tracking decisions: Critical tales of families navigating the course placement process. In M. Sanders \& W. Jordan (Eds) Schooling students placed at risk: Research, policy, practice in the education of poor and minority adolescents (pp. 109-140).

[23] Sanders, M. G., \& Jordan, W. J. (Eds.). (2013). Schooling students placed at risk: Research, policy, and practice in the education of poor and minority adolescents. New York, NY: Routledge.

[24] Federal Bureau of Investigation. (2015). Uniform Crime Reports: Juvenile Arrest Rates by Offense, Sex, and Race (1980-2014). Retrieved online from http://www.ojjdp.gov/ojstatbb/crime/excel/JAR_2014.xls.

[25] Needham, B. L., Crosnoe, R., \& Muller, C. (2004). Academic Failure in Secondary School: The Inter-Related Role of Health Problems and Educational Context. Social Problems, 51(4), 569-586.

[26] Crosnoe, R. (2002). High school curriculum track and adolescent association with delinquent friends. Journal of Adolescent Research,17(2), 143-167.

[27] Miller, S. R. (1998). Shortcut: High school grades as a signal of human capital. Educational Evaluation and Policy Analysis, 20(4), 299-311.

[28] Rosenbaum, J. E., DeLuca, S., Miller, S. R., \& Roy, K. (1999). Pathways into work: Short-and long-term effects of personal and institutional ties. Sociology of education (72), 3, 179-196.

[29] Steinberg, L. D., Brown, B. B., \& Dornbusch, S. M. (1996). Beyond the classroom: Why school reform has failed and what parents need to do. New York, NY: Simon \& Schuster. ISBN: 0684835754.

[30] Becker, G. (1962). Investment in Human Capital: A Theoretical Analysis. Journal of Political Economy, 70(5), 9-49.

[31] Mirowsky J. \& Ross C.E. (2003). Social Causes of Psychological Distress. New York, NY: Hawethorne.

[32] Wilson, W. J. (1978). The declining significance of race. Society, 15(5), 11-11.

[33] Suh, S., Suh, J., \& Houston, I. (2007). Predictors of categorical atrisk high school dropouts. Journal of Counseling and Development: JCD, 85(2), 196. 
[34] Geiser, S., \& Santelices, M. V. (2007). Validity of high-schoo grades in predicting student success beyond the freshman year: High-school record vs. standardized tests as indicators of four-year college outcomes. Center for studies in higher education. IREC: ED502858

[35] Kittelsen Røberg, K. I., \& Helland, H. (2016). Do grades in higher education matter for labour market rewards? A multilevel analysis of all Norwegian graduates in the period 1990-2006. Journal of Education and Work, 1-20.

[36] Aikens, N. L., \& Barbarin, O. (2008). Socioeconomic differences in reading trajectories: The contribution of family, neighborhood, and school contexts. Journal of Educational Psychology, 100, 235-251.

[37] Coley, R. J. (2002). An uneven start: Indicators of inequality in school readiness. Princeton, NJ: Educational Testing Service. ERIC: ED466473.

[38] Palardy, G. J. (2008). Differential school effects among low, middle, and high social class composition schools: A multiple group, multilevel latent growth curve analysis. School Effectiveness and School Improvement, 19, 21-49.

[39] National Center for Education Statistics. (2008). Percentage of high school dropouts among persons 16 through 24 years old (status dropout rate), by income level, and percentage distribution of status dropouts, by labor force status and educational attainment: 1970 through 2007.

[40] Harris, M. B., \& Williams, R. (1985). Video games and school performance. Education, 105(3), 306-309.

[41] Stinebrickner, T. R., \& Stinebrickner, R. National Bureau of Economic Research, (2007). The casual effect of studying on academic performance (Working Paper 1334). Retrieved from website: http://www.nber.org/papers/w13341.

[42] Schmidt, M. E., \& Vandewater, E. A. (2008). Media and attention, cognition, and school achievement. The Future of Children, 18(1), 63-85.

[43] Beard, K. S. (2015). Theoretically Speaking: An Interview with Mihaly Csikszentmihalyi on Flow Theory Development and Its Usefulness in Addressing Contemporary Challenges in Education. Educational Psychology Review, 27(2), 353-364.

[44] Nakamura, J., \& Csikszentmihalyi, M. (2014). The concept of flow. In M. Csikszentmihalyi, Flow and the Foundations of Positive Psychology (pp. 239-263). Chicago, IL: Springer Netherlands.

[45] Csikszentmihalyi, M. (1975). Play and intrinsic rewards. Journal of Humanistic Psychology 15(3), 41-63.

[46] Murphy, C. (2011). Why games work and the science of learning. In Interservice, Interagency Training, Simulations, and Education Conference (pp. 260-272). Retrieved from

http://citeseerx.ist.psu.edu/viewdoc/download?doi=10.1.1.467.354 $3 \&$ rep=rep $1 \&$ type $=$ pdf.

[47] Wang, M. T., \& Eccles, J. S. (2012). Adolescent behavioral, emotional, and cognitive engagement trajectories in school and their differential relations to educational success. Journal of Research on Adolescence, 22(1), 31-39.

[48] Wang, M. T., \& Dishion, T. J. (2012). The trajectories of adolescents' perceptions of school climate, deviant peer affiliation, and behavioral problems during the middle school years. Journal of Research on Adolescence, 52(1), 40-53.

[49] Nelson, J. R., Benner, G. J., Lane, K., \& Smith, B. (2004). Academic achievement of $\mathrm{K}-12$ students with emotional and behavioral disorders. Exceptional Children, 71(1), 59-73.

[50] Anderson, C. A., \& Dill, K. E. (2000). Video games and aggressive thoughts, feelings, and behavior in the laboratory and in life. Journal of Personality and Social Psychology, 78(4), 772.

[51] Hull, J. G., Brunelle, T. J., Prescott, A. T., \& Sargent, J. D. (2014). A longitudinal study of risk-glorifying video games and behavioral deviance. Journal of Personality and Social Psychology, 107(2), 300.

[52] Exelmans, L., Custers, K., \& Van den Bulck, J. (2015). Violent video games and delinquent behavior in adolescents: a risk factor perspective. Aggressive Behavior, 41(3), 267-279.

[53] Olson, C. K., Kutner, L. A., Warner, D. E., Almerigi, J. B., Baer, L., Nicholi, A. M., \& Beresin, E. V. (2007). Factors correlated with violent video game use by adolescent boys and girls. Journal of Adolescent Health, 41(1), 77-83.

[54] Entertainment Software Rating Board. (2016). How much do you know about videogames? Retrieved from http://www.esrb.org/about/video-game-industry-statistics.aspx.

[55] Allen, J. D. (2005). Grades as valid measures of academic achievement of classroom learning. The Clearing House: A
Journal of Educational Strategies, Issues and Ideas, 78(5), 218-223.

[56] Sharma, A. D. (2013). General Intelligence and Emotional Intelligence as Predictors of Academic Success. International Indexed \& Refereed Research Journal 4(46), 26-27.

[57] Qualter, P., Gardner, K. J., Pope, D. J., Hutchinson, J. M., \& Whiteley, H. E. (2012). Ability emotional intelligence, trait emotional intelligence, and academic success in British secondary schools: A 5year longitudinal study. Learning and Individual Differences, 22(1), 83-91.

[58] Cigic, D., Cavar, I., Babic, D., Vasilj, I., \& Martinac, M. (2015). Relationship Between Emotional Intelligence and Personality Types with Success in School. European Psychiatry, 30, 1526.

[59] Saklofske, D. H., Austin, E. J., Mastoras, S. M., Beaton, L., \& Osborne, S. E. (2012). Relationships of personality, affect, emotional intelligence and coping with student stress and academic success: Different patterns of association for stress and success. Learning and Individual Differences, 22(2), 251-257.

[60] Parker, J. D., Summerfeldt, L. J., Hogan, M. J., \& Majeski, S. A. (2004). Emotional intelligence and academic success: Examining the transition from high school to university. Personality and Individual Differences, 36(1), 163-172.

[61] DeBerard, M. S., Spielmans, G. I., \& Julka, D. L. (2004). Predictors of academic achievement and retention among college freshmen: A longitudinal study. College Student Journal, 38(1), 66. Retrieved from

http://www.se.edu/dept/native-americancenter/files/2012/04/PREDICTORS-OF-ACADEMICACHIEVEMENT-AND-RETENTION-AMONG-COLLEGEFRESHMEN.pdf.

[62] Phinney, J. S., Dennis, J. M., \& Chuateco, L. I. (2005). The role of motivation, parental support, and peer support in the academic success of ethnic minority first-generation college students. Journal of College Student Development, 46(3), 223-236.

[63] Wang, M. T., \& Eccles, J. S. (2012). Social support matters: Longitudinal effects of social support on three dimensions of school engagement from middle to high school. Child Development, 83(3), 877-895.

[64] Rienties, B., Beausaert, S., Grohnert, T., Niemantsverdriet, S., \& Kommers, P. (2012). Understanding academic performance of international students: The role of ethnicity, academic and social integration. Higher education, 63(6), 685-700.

[65] Liang, S., Li, H., \& Yang, X. (2014). The Video Game from the Perspective of Positive Psychology. Open Journal of Social Sciences, 2(08), 57.

[66] Seligman, M. E., \& Csikszentmihalyi, M. (2014). Positive psychology: An introduction (pp. 279-298). New York, NY: Springer Netherlands.

[67] Guarini, D. (2013). 9 Ways videogames can actually be good for you. Retrieved from http://www.huffingtonpost.com/2013/11/07/video-games-goodfor-us_n_4164723.html.

[68] Anderson, C. A., \& Bushman, B. J. (2001). Effects of violent video games on aggressive behavior, aggressive cognition, aggressive affect, physiological arousal, and prosocial behavior: A meta-analytic review of the scientific literature. Psychological Science, 12(5), 353-359.

[69] Christakis, D. A., Ebel, B. E., Rivara, F. P., \& Zimmerman, F. J. (2004). Television, video, and computer game usage in children under 11 years of age. The Journal of Pediatrics, 145(5), 652-656.

[70] American Psychology Association. (2013). APA Review Confirms Link Between Playing Violent Video Games and Aggression. Retrieved from

http://www.apa.org/news/press/releases/2015/08/violent-videogames.aspx.

[71] Kasen, S., Cohen, P., \& Brook, J. S. (1998). Adolescent School Experiences and Dropout, Adolescent Pregnancy, and Young Adult Deviant Behavior. Journal of Adolescent Research, 13(1), 49-72.

[72] Parker, J. D., Creque, R. E., Barnhart, D. L., Harris, J. I., Majeski, S. A., Wood, L. M., ... \& Hogan, M. J. (2004). Academic achievement in high school: does emotional intelligence matter? Personality and Individual Differences, 37(7), 1321-1330.

[73] McEvoy, A., \& Welker, R. (2000). Antisocial behavior, academic failure, and school climate a critical review. Journal of Emotional and Behavioral disorders, 8(3), 130-140.

[74] Wang, M. T., \& Fredricks, J. A. (2014). The reciprocal links between school engagement, youth problem behaviors, and school dropout during adolescence. Child Development, 85(2), 722-737. 
[75] Berger, Christian, Alcalay, Lidia, Torretti, Alejandra, \& Milicic, Neva. (2011). Socio-emotional well-being and academic achievement: evidence from a multilevel approach. Psicologia: Reflexão e Crítica, 24(2), 344-351.

[76] Donovan, J. E. (1996). Problem-behavior theory and the explanation of adolescent marijuana use. Journal of Drug Issues, 26(2), 379-404.

[77] Rivkin, S. G., Hanushek, E. A., \& Kain, J. F. (2005). Teachers, schools, and academic achievement. Econometrica, 73(2), 417-458.
[78] Bonner, T. D., \& Aspy, D. N. (1984). A study of the relationship between student empathy and GPA. The Journal of Humanistic Education and Development, 22(4), 149-154.

[79] Perkins, R., Kleiner, B., Roey, S., \& Brown, J. (2004). The High School Transcript Study: A Decade of Change in Curricula and Achievement, 1990-2000. NCES 2004-455. National Center for Education Statistics. New York, NY: Diane Publishing.

[80] Sadler, D. R. (2009). Grade integrity and the representation of academic achievement. Studies in Higher Education, 34(7), 807-826. 